\title{
Ageing and the Welfare State: Securing Sustainability
}

\author{
Volker Meier \\ Martin Werding
}

CESIFO WORKING PAPER No. 2916

CATEgORY 3: SOCIAL PROTECTION

JANUARY 2010

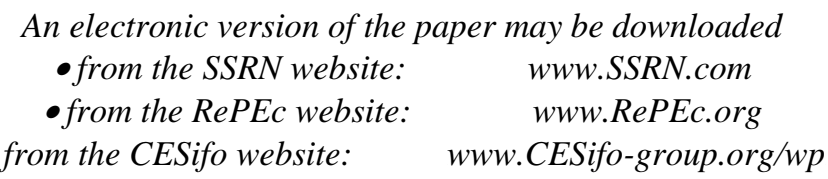




\title{
Ageing and the Welfare State: Securing Sustainability
}

\begin{abstract}
Over the next four decades, increasing old-age dependency ratios exert an enormous upward pressure on welfare spending in most developed countries. As this is mainly due to existing unfunded public pension schemes, many countries have embarked on far-reaching reforms in this area, strengthening actuarial fairness, modifying indexation rules, adding elements of prefunding and, last but not least, attempting to extend the period of economic activity. Efforts to contain costs may also be relevant with regard to public expenditure on health and long-term care but, thus far, no country has started to really deal with these issues. Still, some countries have made substantial progress in securing the long-term sustainability of their welfare systems. What remains to be considered is re-constructing the system of intergenerational transactions as a potential way of removing disincentives to raise children and invest in their human capital in the long run.
\end{abstract}

JEL-Code: H50, H68, J11.

Keywords: demographic ageing, welfare state, public expenditure, fiscal sustainability, policy reforms.

Volker Meier

Ifo Institute for Economic Research \& CESifo at the University of Munich

Poschingerstrasse 5

81679 Munich

Germany

meier@ifo.de
Martin Werding

Ruhr-University Bochum

Room GC 04/311

44780 Bochum

Germany

martin.werding@ruhr.uni-bochum.de 


\section{INTRODUCTION}

While the economic consequences of ageing are open to debate in many other areas, its impact on the welfare state is unambiguous - and all in all rather unfavourable. Patterns of demographic ageing differ substantially across countries. However, in all developed countries it is expected to lead to major shifts in the age composition of total population over the next three to four decades, with a decreasing share of individuals in their active life span and an increasing share of those of retirement age. Given that, the impact of ageing on the welfare state is basically a function of how deeply the state is involved in the areas of old-age provision, provision and/or financing of health services and longterm care, as well as in the fields of child-care, education and financial support for families. Of course, it is also a matter of how the relevant schemes are designed.

Clearly, countries with more generous public pension schemes and heavier public intervention with regard to health and long-term care are facing greater difficulties in keeping these systems sustainable as the process of ageing unfolds. There are considerable cross-country differences regarding the scope and the generosity of the welfare state's activities. But virtually nowhere does the state refrain entirely from engaging in any of the areas mentioned here. Furthermore, a common feature of virtually all programmes applied is that they are - or, at least, have been - mainly based on the pay-as-you-go mechanism. Schemes of this type redistribute from working-age individuals to the old and are thus hit rather immediately by the prospective shifts in demographic fundamentals.

Countries with relatively high levels of public spending on the young may hope for some relief from the demographic strain on their welfare systems through a decreasing share of beneficiaries at this end. Yet, now that the last rounds of a major decline in birth rates are typically twenty to thirty years past, this 'demographic dividend' is likely to be small or even zero in the future. There is no obvious prediction for the trends in welfare expenditure on the working-age population, such as unemployment benefits or social assistance, during the up-coming period of overt demographic ageing. As a consequence, pressures on the welfare state arising from programmes mainly geared towards the elderly will most likely be the dominant effects.

In many countries, the welfare state could definitely not be considered sustainable vis-àvis the prospects of ageing if the legal framework for its main branches had been kept unchanged since the 1980s and 1990s. This prediction has not only been subject to extensive study by researchers in recent years. To a considerable extent, it has even re- 
ceived attention by politicians and the greater public, soliciting debates about reforms virtually everywhere and triggering steps to actually reforming existing welfare programmes in quite a number of cases. This is particularly true with respect to public pension schemes. With regard to financing long-term care, the consequences of ageing are similarly clear-cut, but public involvement in this field is less universal and often spread across different programmes. With regard to health expenditure, disputes remain about the precise nature of effects related to ageing as well as about the significance of further determinants of long-term cost dynamics. In this field, there have thus been numerous attempts at short-term cost containment. But far-sighted, fundamental reforms are basically absent.

The remainder of the paper is organized as follows. In Section II, we highlight demographic trends and their impact on public expenditure in all major branches of the welfare state under constant policies. In Section III, we review recent trends in policy reforms aiming to mitigate the consequences of ageing in several OECD countries. Finally, in Section IV we discusses whether the reforms already implemented appear to be sufficient for making the welfare state sustainable and point to further aspects that may be relevant in this regard.

\section{DEPENDENCY RATIOS AND WELFARE EXPENDITURE}

\section{II.1 Demographic Dependency: Projected Changes}

Probably the most important indicator of demographic ageing and its consequences for the welfare state is given by the old-age dependency ratio (OADR). It is conventionally defined as the number of individuals aged 65 and over per individuals aged 15 to 64 in the population of a given country. This ratio feeds through, though not necessarily on a one-for-one basis, to the systems' dependency ratios of many welfare programmes, e.g., the ratio of pensioners over contributors in the working-age population, or the ratio of older individuals with higher average health costs over prime-aged individuals making net contributions to actually funding these costs. The OADR of course neglects the fact that many individuals aged 15-64 are still enrolled in secondary or tertiary education, do not participate in the labour force for various reasons, are unemployed or have already entered early retirement. But it describes the demographic fundamentals for financing benefits that mainly accrue to the elderly. An important qualification is that, while influencing the time path of the OADR is difficult even over a longer time hori- 
zon, behavioural and institutional features affecting the labour market status of individuals of a given age may be subject to political action.

Figure 1: Old-age Dependency Ratios in OECD Countries, 2000, 2025 and 2050

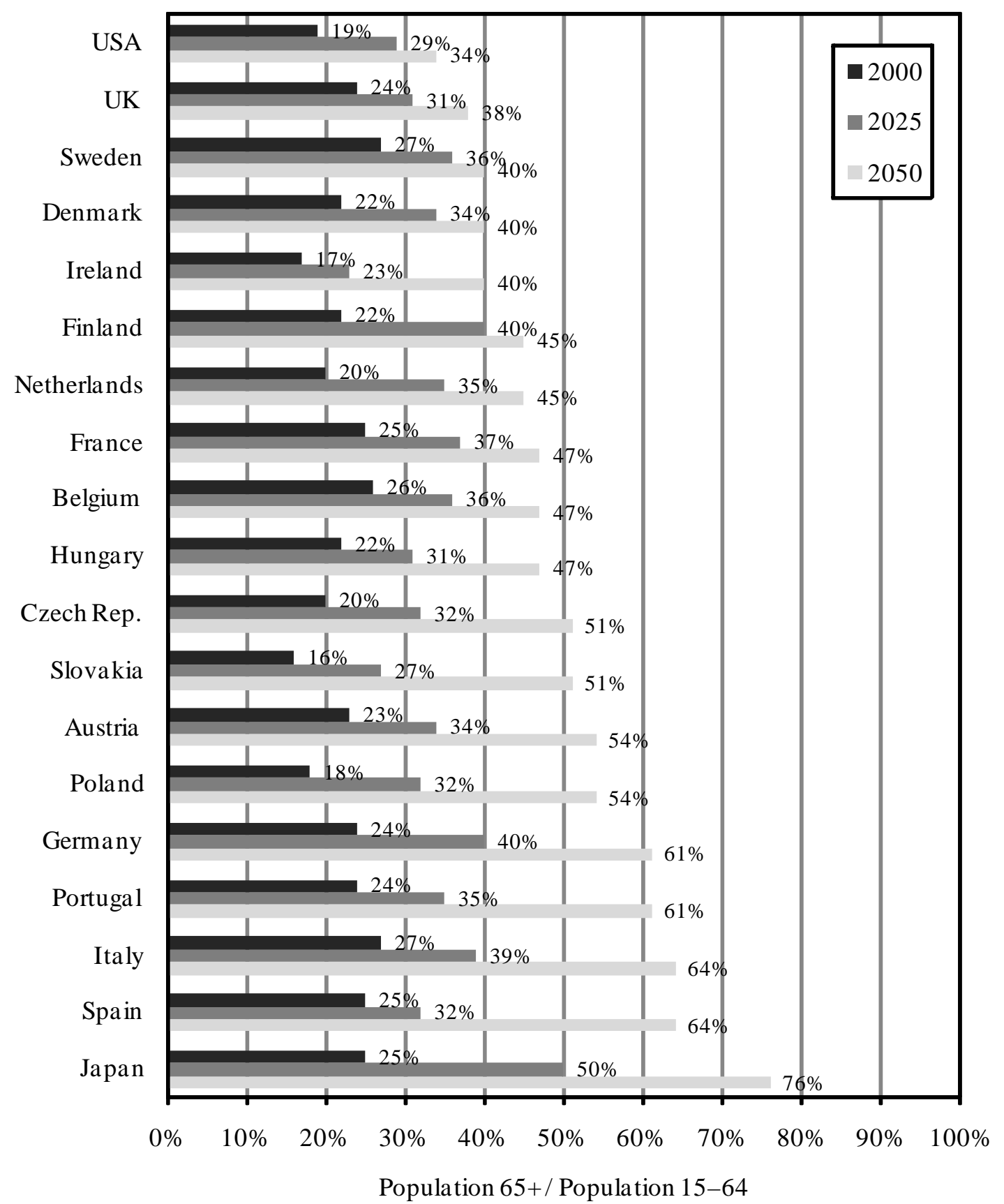

Source: UN Population Division (2009), constant-fertility variant.

Figure 1 shows expected changes in the OADR for a number of OECD countries over the next decades. In the US, with a relatively high fertility rate, the ratio was at a low 
level of $19 \%$ in the year of 2000 . It is expected to increase to $29 \%$ until 2025 and to $34 \%$ until 2050. In Japan, the OADR was at $25 \%$ in 2000, and it is projected to increase to $50 \%$ until 2025 and to $76 \%$ until 2050 (UN Population Division, 2009). ${ }^{1}$ Most other developed countries lie in between these two scenarios, implying that the number of older people per individuals of working age will increase by between 50\% and 200\% and will typically more than double over the time period considered here. If labour force participation remains as it is and if contribution rates are kept constant, this means that the quasi-replacement rates of pension benefits, measuring the ratio of average pensions over average wages, will drop by $33 \%$ to $66 \%$. If replacement rates were kept constant a wide-spread feature of pension policies in many countries until the 1990s - contribution rates would have to increase by the same rate as the OADR.

Purely demographic effects for health costs are likely to be less dramatic. Age-specific per-capita expenditure on health is typically increasing around the retirement age, but an important fraction of total health costs is still falling on younger individuals. In some countries, the state actually concentrates on covering health costs of the elderly, implying that expenditure in these programmes could nevertheless grow in line with the OADR. At the same time, it is possible that age-specific health risks, hence age-related health costs at higher ages, may decline with longer life expectancy, thus taking away some of the demographic upward pressure.

For long-term care, dependency ratios that would be similarly informative should probably consider individuals aged 85 and over compared to the number of individuals aged 15 to 64. These dependency ratios grow even much faster than the standard OADR because they are much more affected by increases in life expectancy. Unlike public pensions, however, long-term care has to be financed only for some of the elderly, so that the upward pressure on public expenditure in this area is less worrying on absolute terms. Also, age-specific prevalence rates may decline over time as the population lives longer. Furthermore, the state typically covers only a fraction of total costs of long-term care, e.g., through social insurance schemes with caps on current costs covered or through programmes specifically addressing the needy.

1 Here, we rely on the 'constant-fertility' variant of the latest release of the United Nations' World Population Prospects. In their 'medium' variant, the UN Population Division assumes that, throughout the world, fertility rates converge towards 1.85 in a long-term process. In the absence of any changes in behaviour and relevant institutions, this assumption appears to be less plausible for quite a number of developed countries. 
Figure 2: Total Dependency Ratios in OECD Countries, 2000, 2025 and 2050

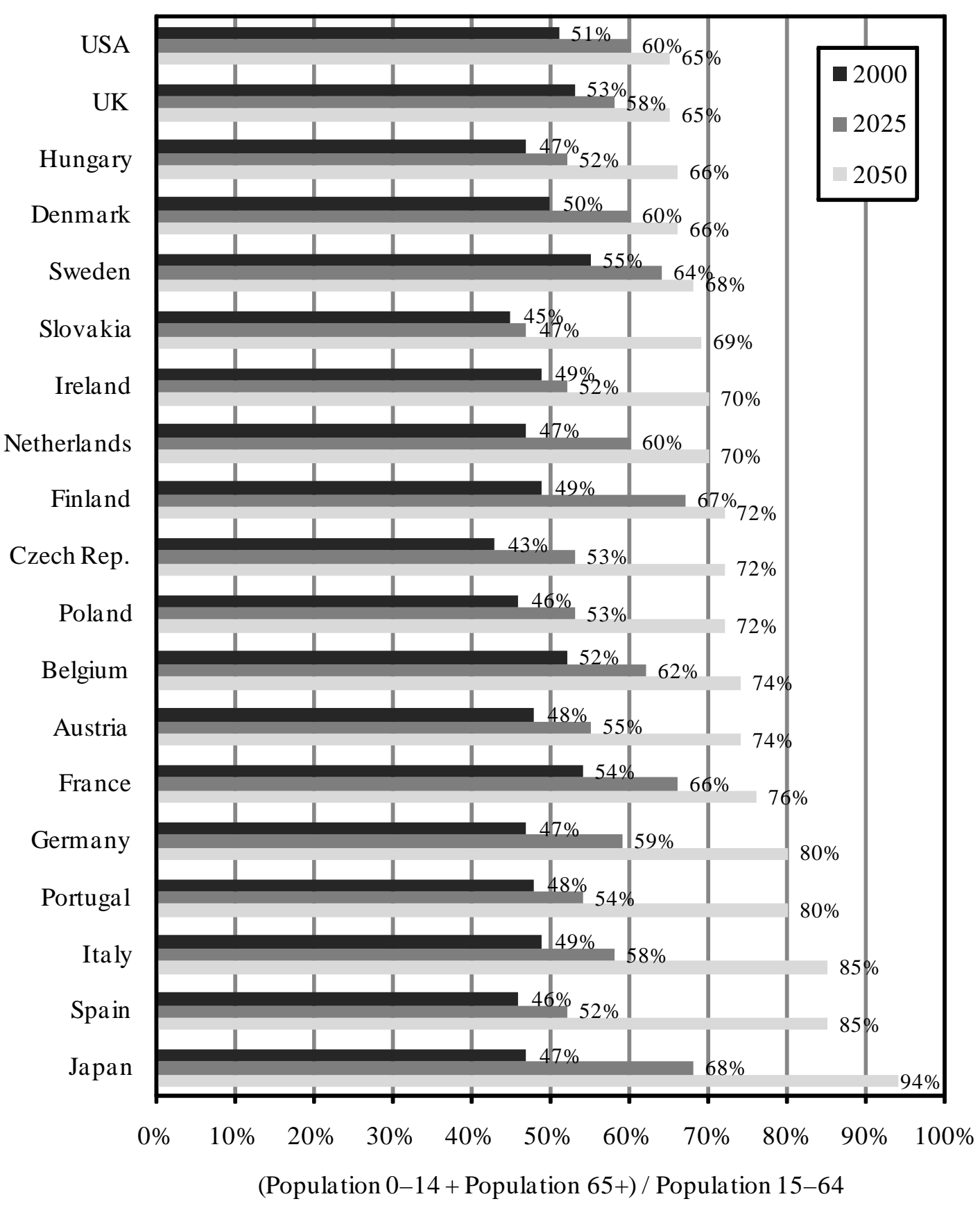

Source: UN Population Division (2009), constant-fertility variant.

Another indicator that is potentially important with respect to the consequences of ageing is the total dependency ratio (TDR), relating the number of children below age 15 plus the number of elderly people aged 65 and over to the number of individuals aged 15 to 64 . To the extent that ageing is driven by a decline in fertility, the youth- 
dependency component of this measure decreases over time. This may compensate to some extent for the heavier burden involved in higher old-age dependency.

Indeed, the rise in total dependency is typically less pronounced than the increase in the OADR (see Figure 2). In the US, total dependency is projected to increase from $51 \%$ in 2000 to $65 \%$ in 2050; in the UK the respective figures are 53\% and 65\%. Countries that are facing a sharp increase in old-age dependency and, at the same time, have a low fertility rate already today should expect far stronger increases in the TDR. For example, in Germany the ratio increases from $47 \%$ in 2000 to $80 \%$ in 2050, and in Japan it rises from $47 \%$ to $94 \%$ (UN Population Division, 2009). Clearly, in countries where fertility has already been low for several decades, the number of youths relative to that of working-age individuals will not decrease much further in the future. The relief for workers who have to take care for fewer children through child-related benefits and education financed from the government budget will thus be small or even insignificant.

In public discussions it is sometimes asserted that benefits related to unemployment among the working-age generation should become less pressing in the ageing process as it is often associated with a shrinking workforce. By this naïve view, unemployment rates should decline as soon as the number of retiring workers exceeds the number of individuals entering the labour market. This conclusion ignores that there are institutional determinants of unemployment. For instance, wage setting may counteract the demographic processes if bargaining parties take into account both the shrinking labour supply and the expected increase in wage taxes which are needed to finance for increasing old-age dependency. In fact, the financial burden for those in employment may well rise through higher benefits paid to members of their own generation, given that higher wage taxes could trigger higher unemployment through more aggressive wage setting.

\section{II.2 The Impact on Welfare Expenditure If Policies Remain Unchanged}

All in all, changes in the age structure of the population expected for the next three to four decades exert an enormous upward pressure on welfare expenditure in most industrialized countries. To illustrate this, let us consider some simple estimates regarding a 'constant-policy' scenario for changes in age-related public expenditure in the OECD countries looked at so far. Here, 'constant policy' is taken to indicate that eligibility rules, benefit levels and, most generally speaking, the extent of public involvement in any of the relevant branches of welfare expenditure remain as they were before ageing became really acute. Consequently, we also abstract from any behavioural changes on 
the side of future beneficiaries. Note that actual policies which have been legislated to deal with the consequences of ageing are often phased in over a longer period of time. They are thus rarely constant in this sense. Our calculations are based on year-2000 figures for welfare expenditure per GDP taken from the OECD SOCX (2008) database. Until 2000, far-reaching policy responses to the prospects of ageing were less common than they have been since then. More importantly, where major reforms had been taken well before this year - most notably in the US in 1983 or in Italy in 1992/95 - their impact on current expenditure in 2000 was still limited through long transition periods. ${ }^{2}$

Table 1 shows how the major age-related branches of public welfare expenditure would evolve between 2000 and 2050 if, under the demographic scenarios illustrated in Figures 1 and 2, the legal framework remained entirely unchanged. More specifically, our hypothetical calculations are based on the following assumptions.

- Public old-age pensions and survivor benefits per capita of the population aged 65 and over remain constant as a share in GDP per worker, with the employment-to-population ratio among those aged 15 to 64 being constant as well. Therefore, expenditure on these items changes in line with the expected increase in the OADR.

- Public expenditure on health care which can be attributed to individuals aged 65 and over based on national institutions and a typical age profile of total health costs (European Commission and Economic Policy Committee, 2009, Sect. 3.2) changes in line with (i) the expected increase in the OADR, (ii) an extension of years in good health corresponding to expected increases in life expectancy.

- Public expenditure on long-term care is projected in basically the same way as health expenditure, concentrating (i) on changes in old-age dependency for those aged 85 and over and (ii) on shifts in age specific prevalence rates and costs (European Commission and Economic Policy Committee, 2009, Sect. 10.2) which again parallel expected increases in life expectancy.

- Public spending on child benefits, pre-primary child care and compulsory schooling (i.e., primary to upper secondary education) per capita of the population in the relevant age groups remains constant as a share in GDP per worker. Thus, it basically changes in line with expected shifts in youth dependency.

\footnotetext{
In the US, this applies to the increase in the age threshold for claiming full benefits: in 1983, it was scheduled to increase from age 65 to 67 starting from the year 2002. Another major element of the early reforms taken in the US, viz. the expansion of the Social Security Trust Funds, was not about curtailing future expenditure, but about how they shall be financed.
} 
- Public spending on unemployment benefits and other transfers to individuals of working age are not mainly driven by ageing. For simplicity, it is therefore assumed to remain constant in terms of GDP per worker and, hence, ignored here.

By these assumptions as well as in terms of the projection methods applied, our exercise is much in the spirit of early attempts at assessing the impact of ageing on public pension schemes (see, e.g., Hagemann and Nicoletti, 1989; Roseveare et al., 1996). Our calculations are broader in scope, covering all categories of welfare-state expenditure that are clearly age-related. Furthermore, they are not meant to give a picture of actual developments, but to demonstrate the upward pressure exerted on public expenditure purely through demographic trends. ${ }^{3}$

Table 1 reveals that the potential impact of ageing on welfare expenditure is very strong in many developed countries. From 2000 to 2050, the hypothetical increase in expenditure on old-age pensions, survivor benefits, health care and long-term care, corrected for potential reductions in expenditure on child benefits and public schooling, amounts to only $2.1 \%$ of GDP in the UK. At the same time, it is $7.6 \%$ in the US, no less than $11.5 \%$ in France and over 20\% in Japan and Germany. By far the most important driver of these changes is pension expenditure under the assumption of constant eligibility rules, benefit levels and retirement behaviour. The impact of public health expenditure varies substantially. In spite of assumptions that are plausible, but relatively mild, its resulting increase is considerable in the US and definitely strong in Germany and Japan. Reductions in expenditure on children are small everywhere, exceeding 1\% of GDP only in Austria and in several transition countries which are otherwise rather strongly affected by the impact of ageing on their welfare expenditure.

Whatever the precise definition of 'sustainability', it appears that the welfare state could not be considered sustainable in the majority of countries considered here in a 'constantpolicy' scenario based on year-2000 figures for benefit expenditure and current prospects for demographic ageing until 2050. Thus far, however, we have deliberately ignored the many steps to reform, some incremental in their nature and some very farreaching, which have been taken in many developed countries in order to deal with this unfavourable outlook.

3 Our calculations may overstate this pressure as they ignore numerous details in eligibility rules involved in national law, inferring their impact from demographic proportions. Otherwise, some care has been expended on preparing plausible ‘constant-policy' scenarios for the consequences of ageing on public welfare expenditure, taking into account detailed, high-quality data and some of the wisdom deriving from more realistic projection exercises, such as those conducted by the OECD (2001, ch. 4) or the European Commission and the Economic Policy Committee (2006; 2009). 
Table 1: Age-related public expenditure in OECD countries, hypothetical increase under 'constant' policies

\begin{tabular}{|c|c|c|c|c|c|c|c|c|}
\hline & \multicolumn{2}{|c|}{$\begin{array}{l}\text { Old-age \& Survi- } \\
\text { vor Pensions }\end{array}$} & \multicolumn{2}{|c|}{$\begin{array}{l}\text { Health care } \\
\text { \& LTC }\end{array}$} & \multicolumn{2}{|c|}{$\begin{array}{l}\text { Child benefits } \\
\text { \& education }\end{array}$} & \multicolumn{2}{|c|}{ Total } \\
\hline & $\begin{array}{l}\text { Level } \\
2000\end{array}$ & $\begin{array}{c}\text { Change } \\
2000 \\
\text { to } 2050\end{array}$ & $\begin{array}{l}\text { Level } \\
2000\end{array}$ & $\begin{array}{c}\text { Change } \\
2000 \\
\text { to } 2050\end{array}$ & $\begin{array}{l}\text { Level } \\
2000\end{array}$ & $\begin{array}{c}\text { Change } \\
2000 \\
\text { to } 2050\end{array}$ & $\begin{array}{l}\text { Level } \\
2000\end{array}$ & $\begin{array}{c}\text { Change } \\
2000 \\
\text { to } 2050\end{array}$ \\
\hline & \multicolumn{8}{|c|}{$\%$ of GDP } \\
\hline UK & 5.4 & +3.0 & 6.2 & -0.4 & 6.7 & -0.6 & 18.3 & +2.1 \\
\hline Sweden & 9.2 & +4.7 & 7.0 & -0.5 & 7.6 & -0.2 & 23.7 & +4.0 \\
\hline Denmark & 6.3 & +4.9 & 6.8 & +1.5 & 8.2 & -0.3 & 21.2 & +6.1 \\
\hline Ireland $^{\mathrm{a}}$ & 3.7 & +5.2 & 5.6 & +2.3 & 5.4 & -0.4 & 14.7 & +7.1 \\
\hline USA & 5.9 & +4.8 & 5.9 & +3.1 & 4.9 & -0.2 & 16.7 & +7.6 \\
\hline Hungary & 7.6 & +8.5 & 5.2 & +1.3 & 6.4 & -1.4 & 19.2 & +8.4 \\
\hline Belgium & 7.6 & +6.4 & 8.0 & +2.4 & 6.6 & \pm 0.0 & 22.2 & +8.7 \\
\hline Netherlands & 4.5 & +5.6 & 6.2 & +3.5 & 5.2 & -0.4 & 15.9 & +8.8 \\
\hline Finland & 7.7 & +7.8 & 5.9 & +2.2 & 6.8 & -0.1 & 20.4 & +9.9 \\
\hline France & 11.0 & +9.8 & 8.3 & +1.7 & 7.8 & \pm 0.0 & 27.1 & +11.5 \\
\hline Czech Rep. & 7.7 & +12.2 & 6.2 & +3.3 & 5.1 & -0.6 & 19.0 & +14.9 \\
\hline Portugal & 8.2 & +12.7 & 6.5 & +3.1 & 5.2 & -0.9 & 19.9 & +14.9 \\
\hline Spain & 8.4 & +13.4 & 5.6 & +3.3 & 4.6 & \pm 0.0 & 18.7 & +16.6 \\
\hline Slovakia & 6.3 & +13.5 & 5.1 & +4.5 & 2.9 & -1.1 & 14.4 & +16.8 \\
\hline Austria & 11.7 & +15.9 & 7.5 & +4.2 & 7.1 & -1.4 & 26.3 & +18.7 \\
\hline Italy & 13.6 & +18.4 & 5.9 & +2.2 & 4.7 & -0.1 & 24.2 & +20.4 \\
\hline Germany & 10.3 & +15.9 & 8.6 & +5.6 & 5.5 & -1.0 & 24.4 & +20.5 \\
\hline Japan & 7.0 & +14.0 & 7.1 & +8.5 & 3.8 & -0.6 & 17.9 & +21.9 \\
\hline Poland & 10.3 & +21.0 & 4.2 & +3.7 & 5.1 & -1.9 & 19.6 & +22.8 \\
\hline
\end{tabular}

a) Figures for Ireland are expressed in \% of Gross National Income.

Sources: OECD SOCX (2008); UN Population Division (2009), constant-fertility variant; own calculations.

\section{TRENDS IN POLICY REFORMS}

It is impossible to provide a full overview of policy measures aiming at improvements in the short-term and long-term fiscal stance of all branches of the welfare state which have been taken in OECD countries in recent years. As a stylised fact, many countries have embarked on serious approaches to reforming their pension systems, while little has been done about financing health care or long-term care that goes beyond some 
short-term cost containment. In this section, we will therefore concentrate on highlighting major trends in national pension policies, some of which could also be applied to other branches of the welfare state. Also, improvements in labour market performance can have a strong impact on the long-term perspectives for financing the welfare system. We will thus include these issues as an aside.

\section{III.1 Strengthening Actuarial Fairness}

Where the earlier design of public pension schemes left room for that, authorities have often taken measures to strengthen actuarial fairness within these schemes. Even in many 'Bismarckian' pension schemes with a notable tax-benefit link, benefit assessment was traditionally based on a limited number of 'best years' with highest contributions, or on end-of-career levels of covered earnings. Actuarial adjustments then imply that benefits are now more and more assessed based on life-long earnings. Examples of relevant reforms are given by Italy (in a first round of reforms enacted in 1992), France (in 1993 and, again, in 2003) or Austria (in 2003). In addition, many pension schemes used to provide non-contributory benefits tied to specific contingencies or periods typically not covered with contributions. Often, entitlements of this kind have been scaled back through series of incremental changes, e.g., in Germany (between 1992 and 2001). Exceptional and extreme steps to abolishing non-contributory benefits were made in Sweden, where survivor benefits were essentially wiped out (in 1990) and where the traditional pension system combining universal lump-sum benefits with earnings-related pensions for employees was transformed (in 2000) into a pension scheme which is now probably more Bismarckian than the German one. The main goal of such reforms is to reduce the tax-like character of contributions, thus promoting labour supply across the board.

On the other hand, countries that mainly rely on 'Beveridgean' pension schemes with lump-sum benefits in their public pillar of old-age provision, have often tried to make sure that their systems really provide an adequate basic cover, effectively expanding the interpersonal redistribution of income involved in these schemes. Here, the most prominent example is given by the UK (from 2002 onwards), with a revitalisation of the Basic State Pension and remarkable changes in the legal framework for supplementary, or second, public pensions, effectively making the latter less and less earnings-related.

Another field where actuarial principles have often been strengthened are the options to retire early drawing on public pensions (or other benefits that define an exit route from 
labour force participation to retirement). When unemployment was high in the 1980s and early 1990s, virtually all countries in continental Europe created incentives in favour of early retirement, implying that the average age of retirement often became rather low there (see Fenge and Pestieau, 2005). As this strategy which was also meant to promote employment among younger individuals did not work, it was later terminated and even reversed. As a rule, individuals who want to retire before they reach a certain age threshold are now faced with reductions in pension benefits through shorter periods with contributions as well as special deductions to compensate for their longer duration of benefits. These benefit deductions are not always actuarially fair in a strict sense, implying that the pension scheme is still not entirely neutral with respect to the timing of retirement. But they clearly reduce third-party payments involved in the old framework for retirement decisions and contribute to cutting aggregate pension expenditure.

\section{III.2 Switching From DB to NDC}

Next to rules applying to the assessment of benefits at award, rules for indexing pension benefits over time are also important determinants of the long-term trends in pension expenditure. Traditionally, most public pension schemes employ indexation rules by which benefits are regularly up-rated in line with wages, prices, or some mixture between these two approaches. Within this range of options, it is thus possible to switch from a more generous to a less generous variant. For example, Germany switched from gross to net wage indexation (in 1992), and France switched from wage indexation to a US-style, mixed indexation regime (in 1993), that is, to an assessment of individual benefits based on wage indexation of previous earnings, followed by annual up-ratings based on price indexation. In contrast, the UK moved from price indexation of benefits and all relevant thresholds by which the Basic State Pension eroded substantially during the 1980s and 1990s to a mixed regime with wage up-ratings of benefits (in 2002).

Basically, indexation rules are elements of pension schemes which fall into the DB ('defined benefits') category: in these systems, benefits are determined and indexed so as to provide some defined amount or, rather, level of benefits. Contribution rates or taxes then have to be adjusted to meet the system's current financial obligations. As a new strategy for coping with the ageing problem, a few countries changed this logic, establishing what is now called NDC ('notionally defined contributions') schemes. In these schemes, contribution rates are essentially fixed at a level which, for various reasons, should not be exceeded. The level of benefits then becomes endogenous, corresponding 
to what can be financed for individual beneficiaries given this contribution rate and the current systems' dependency ratio. Two countries that openly adopted NDC-type rules are Italy (in 1995) and Sweden (in 2000). Germany introduced a demographic factor into its indexation formula (in 2004) by which an increase in the dependency ratio feeds back on benefit up-ratings, implying that the German statutory pension scheme is now situated somewhere between a traditional DB and an NDC arrangement.

The application of actuarial principles to public pay-as-you-go pension schemes and a switch from defined benefits to defined contributions are both inspired by features of private, funded pension schemes. Noting that large-scale demographic ageing may also cause problems for funded schemes, but has a negative first-order effect only on unfunded pensions (Brooks 2000; Börsch-Supan et al., 2003; Fehr et al., 2005), there have been intensive discussions as to whether funding offers a meaningful option for dealing with the ageing problem.

\section{III.3 Is Funding a Way Out?}

When ageing first appeared to become an issue, a widely-held view among economists was that unfunded public pension schemes are effective in securing some amount of old-age provision for all those covered, albeit at a low rate of return. The internal rate of return to contributions made to these systems is the rate of payroll growth, which must be expected to fall short of the market rate of interest over longer periods of time. Many economists concluded that converting unfunded systems into funded ones, while paying off all existing unfunded liabilities, should lead to welfare gains (see, e.g., Feldstein, 1995). However, Breyer (1989) and Fenge (1995) demonstrated that this view is flawed. The pay-as-you-go mechanism as such is 'intergenerationally efficient' in the sense that transforming unfunded pension schemes into funded schemes is impossible without harming at least some generation. The burden involved in ageing can thus be shared in various ways between future generations, the active generation and those in retirement, but it can never be removed (see also Fenge and Werding, 2004).

Yet, even if pre-funding is not unambiguously superior, there are still good reasons to expand the share in old-age income which is derived from funded pension plans when the return to unfunded schemes becomes even lower - for the young in a DB-type scheme, for the old under NDC rules - because of the demographic pressure. Additional considerations regarding risk diversification aside, the simple logic of such policies is to use financial and real capital as a substitute for human capital, by which pay-as-you-go 
schemes are effectively funded, now that the latter is increasingly lacking (for a pronounced exposition, see Sinn 2000). Consequently, a number of countries have gone in this direction, either building up 'demographic buffer funds' inside their public pension schemes, as in the US (in 1983), Finland (in 1997), Ireland (in 1999), or Spain (in 2001); establishing new mandatory plans supplementing public pensions, as in Denmark (in 1999) or Sweden (in 2000); or subsidising private, voluntary provisions, as in Germany (in 2001) or France (in 2003). Where complementary funding is meant to partially replace mandatory public old-age provision, making sure that individuals really participate may become important, at least in the sense that gaps in coverage through existing occupational or private pension plans could be filled through an automatic enrolment, as in the UK (starting from 2012). Otherwise, all these arrangements have specific merits and risks, an important issue being how they perform with respect to the potential tradeoff between transaction costs involved and the scope for choice given to investors, which needs to be seen in most cases.

\section{III.4 Creating a Framework for Longer Working Lives}

Many countries, especially in Europe, are still struggling to increase the effective age of retirement beyond age 60 and to increase the statutory retirement age to 65, which appears to be the current international standard for men and women alike. Meanwhile, a few countries have already started to increase the age threshold for claiming full benefits from 65 to 67 . The first country taking this measure were the US, where a schedule was devised at a rather early stage (in 1983) by which the new age limit is phased in now from 2002 to 2027. More recently, Germany adopted a similar schedule (in 2007, phased in from 2012 to 2031). In Denmark, the statutory retirement age had been at 67 until a few years ago, while the effective retirement age was substantially lower through generous early retirement rules. Now, the statutory limit will be increased from age 65 to 67 again (enacted in 2009, taking effect from 2024 to 2027) and then linked to the conditional life expectancy at age 60.

Expanding the period of economic activity as longevity increases directly addresses a major cause of the impact of ageing on public pension schemes. Furthermore, it is a powerful instrument to slow down expected increases in systems' dependency ratios, affecting both the numerator and the denominator of this figure. As a consequence, it may allow for paying higher annual benefits to future pensioners than under any of the other approaches to reform discussed before - albeit for a shorter period of their lives (see Werding, 2007, for a demonstration of these effects taking the German reform as an 
example). All this is true, of course, only if individuals are really able to stay active for a longer period of their lives. Note that, in this regard, sickness and incapacity need not be limitations of growing importance as it can be expected that a major share of additional years of life expectancy is spent in good health.

In countries where structural unemployment is high, or where labour-force participation of particular groups - most notably among women and older workers - is relatively low, labour market reforms and other measures aiming to overcome these problems are useful for various reasons. Successful policies in both these areas are also important prerequisites for dealing with the ageing problem, if only for their positive impact on employment and GDP. Aspects which are particularly important for serious attempts at expanding the active life span of individuals relate to the supply of, and the demand for, older workers. For this strategy to work, several kinds of adjustments are required. First, individuals need to adapt their life-cycle plans, a major condition being that the changes in relevant rules are announced in good time. Second, firms may have to re-consider their current habits regarding additional training for older workers, and they may also have to think about working conditions and new jobs which are suitable for people working until age 65 and beyond. Last but not least, further adjustments in labour market institutions and welfare schemes are needed as they still tend to accommodate early exits from the labour market in many ways. Where steps in this direction have been made, e.g. through changes in job search requirements for unemployed individuals aged 55 and over, closure of retirement pathways through systems providing unemployment benefits, sickness or incapacity benefits etc., the experience appears to encouraging (see, e.g., Whiteford, 2006; OECD, 2006).

\section{IS SUSTAINABILITY SECURED?}

\section{IV.1 How to Define Sustainability?}

Calculations like those presented in Section II easily support the conclusion that the sustainability of welfare programmes is threatened by the consequences of ageing if policies remain unchanged. When discussions about these issues started, 'sustainability' was mainly seen as a political category, essentially referring to increases in contribution rates and/or reductions in benefit levels that appeared to be politically feasible. In the meantime, the concept has been given some economic content, building on the observation that unfunded benefit entitlements offered by many welfare schemes constitute an implicit type of public debt and on the idea that the government has to meet an inter- 
temporal budget constraint when paying off this implicit as well as all explicit debt (see Blanchard, 1990; Auerbach et al., 1991; or for a critical assessment, Haveman, 1994). Projected increases in expenditure ratios are effectively one way in which the implicit debt will become apparent over time if contributions or taxes are not increased correspondingly. It is also possible to directly calculate the amount of implicit liabilities involved in existing welfare programmes. However, the results are difficult to interpret, not only because they often appear to be enormously high when compared to official, explicit debt figures, or because they are extremely sensitive to assumptions regarding future interest rates, but above all because some amount of total public debt is sustainable, while it remains unclear, how much.

In their attempts to monitor public finances under the EU Stability and Growth Pact, the Economic Policy Committee (2003; EPC) has therefore developed simple, illustrative 'sustainability-gap' measures which are now regularly applied to assessing the longterm sustainability of public finances in EU member states with an eye on the prospects of demographic ageing. The most comprehensive variant of these measures accounts for projected increases in benefit expenditure in all major branches of the welfare state over a virtually infinite time horizon. The sustainability gap then corresponds to a constant percentage of GDP by which annual 'primary' deficit ratios (leaving out interest payments on existing debt) in the general-government budget would have to be improved against a baseline, or current-policy, scenario in each year starting from now in order to smooth the fiscal burden of ageing over time and to observe the government's intertemporal budget constraint. Improvements in deficit ratios can be brought about by corresponding expenditure cuts or tax increases, probably with asymmetric effects through behavioural changes which are induced in either case, or through a broader class of policies suited to stimulate the growth of GDP as the reference figure for these ratios.

IV.2 The Impact of Ageing on Welfare Expenditure Under Actual Policies

To illustrate the current stance of public finances as a whole, and of welfare expenditure in particular, in terms of their long-term sustainability, let us first return to projected increases in public age-related expenditure (as in Table 1) now referring to recent, more subtle projections conducted by the European Commission and the Economic Policy Committee (2006), respectively by the OECD (2001, ch. 4) for non-EU member coun- 
tries. ${ }^{4}$ The results (see Table 2) are meant to show the consequences of current policies pursued in each country, including changes which have already been legislated, but will become effective only over time. The table also displays results for the EPC's sustainability gap which have been calculated building on these expenditure projections by the European Commission (2006) and by Hauner et al. (2007).

In Table 2, countries are ranked according to the strength of the impact of ageing on total age-related expenditure. A ranking according to the size of the sustainability gap would be similar, but not identical since the latter is also affected by the initial amount of (explicit) public (net) debt, also reflecting the extent of pre-funding for future benefit expenditure, and by the initial budgetary position. The table shows that, under actual policies which have been devised for the future, expected increases in welfare expenditure are substantially smaller in most cases than is suggested by purely demographic trends (cf. Table 1). In particular, where they have been made, pension reforms strongly contribute to improving the fiscal sustainability of the welfare state as this is where the reductions mainly come from. Another remarkable observation is that reforms appear to have been strongest where the pressure involved in ageing is most imminent.

A downside involved in far-reaching pension reforms which often came in several rounds is that expected reductions in replacement rates are now so strong that future old-age poverty becomes an issue of major concern in a number of developed countries. To reflect this in their records of recent pension reforms, the OECD (2009, ch. I.3) has now introduced a new category of potential reform goals, viz. the 'adequacy' of provisions. Ironically, many measures that are listed there would be mentioned again under other goals, such as 'economic efficiency' or 'financial sustainability', if they were soon rolled back or abandoned. This points to material conflicts which certainly cannot be solved when setting up a synopsis of pension policies pursued in different countries. Striking the right balance between these conflicting goals in ageing societies is clearly a challenge for policy making which needs to be addressed at the national level. We may add here that, if public pensions have to be cut back to become sustainable, making complementary savings mandatory and extending the period of employment are certainly among the few options that remain.

\footnotetext{
The OECD involved national experts in their large-scale projection exercise and clearly directed them in their work to make the results comparable. Borrowing much of the methodology from the OECD, the Ageing Working Group of the EU Economic Policy Committee, supported by other Commission services, prepared up-dated projections for the EU-25 member states five years later. More recent updates with projections for EU-27 member states until 2060 have just been released in European Commission and Economic Policy Committee (2009).
} 
Table 2: Age-related public expenditure in OECD countries, projected increase under current policies

\begin{tabular}{|c|c|c|c|c|c|c|c|c|c|}
\hline & \multicolumn{2}{|c|}{$\begin{array}{l}\text { Public } \\
\text { Pensions }\end{array}$} & \multicolumn{2}{|c|}{$\begin{array}{l}\text { Health care } \\
\text { \& LTC }\end{array}$} & \multicolumn{2}{|c|}{ Education } & \multicolumn{2}{|c|}{ Total } & \multirow{2}{*}{$\begin{array}{c}\text { Sustain- } \\
\text { ability } \\
\text { gap }^{\text {c }}\end{array}$} \\
\hline & $\begin{array}{l}\text { Level } \\
2004\end{array}$ & $\begin{array}{c}\text { Change } \\
2004 \\
\text { to } 2050\end{array}$ & $\begin{array}{l}\text { Level } \\
2004\end{array}$ & $\begin{array}{l}\text { Change } \\
2004 \\
\text { to } 2050\end{array}$ & $\begin{array}{c}\text { Level } \\
2004\end{array}$ & $\begin{array}{l}\text { Change } \\
2004 \\
\text { to } 2050\end{array}$ & $\begin{array}{c}\text { Level } \\
2004\end{array}$ & $\begin{array}{l}\text { Change } \\
2004 \\
\text { to } 2050\end{array}$ & \\
\hline & \multicolumn{9}{|c|}{$\%$ of GDP } \\
\hline Poland & 13.9 & -5.9 & 4.2 & +1.5 & 5.0 & -1.9 & 23.1 & -6.3 & -2.5 \\
\hline Austria & 13.4 & -1.2 & 5.9 & +2.5 & 5.1 & -1.0 & 24.4 & +0.3 & -1.5 \\
\hline Italy & 14.2 & +0.4 & 7.3 & +2.0 & 4.3 & -0.6 & 25.8 & +1.8 & -0.8 \\
\hline Sweden & 10.6 & +0.6 & 10.5 & +2.7 & 7.3 & -0.9 & 28.4 & +2.4 & +1.2 \\
\hline Germany & 11.4 & +1.7 & 7.0 & +2.2 & 4.0 & -0.9 & 22.4 & +3.0 & +1.3 \\
\hline Slovakia & 7.2 & +1.8 & 5.1 & +2.5 & 3.7 & -1.3 & 16.0 & +3.0 & +2.8 \\
\hline Japan $^{\mathrm{a}}$ & 7.9 & +0.6 & 5.8 & +2.4 & n.a. & n.a. & 13.7 & +3.0 & +6.2 \\
\hline France $^{b}$ & 12.8 & +2.0 & 7.7 & +1.8 & 5.0 & -0.5 & 25.5 & +3.3 & +2.2 \\
\hline UK & 6.6 & +2.0 & 8.0 & +2.7 & 4.6 & -0.6 & 19.2 & +4.1 & +2.8 \\
\hline Denmark & 9.5 & +3.3 & 8.0 & +2.1 & 7.8 & -0.3 & 25.3 & +5.1 & -0.8 \\
\hline Netherlands & 7.7 & +3.5 & 6.6 & +1.9 & 4.8 & -0.2 & 19.1 & +5.2 & +4.2 \\
\hline $\mathrm{USA}^{\mathrm{a}}$ & 4.6 & +2.1 & 2.6 & +4.4 & 3.9 & -1.0 & 11.1 & +5.5 & +6.9 \\
\hline Finland & 10.7 & +3.1 & 7.3 & +3.2 & 6.0 & -0.7 & 24.0 & +5.6 & +2.2 \\
\hline Belgium & 10.4 & +5.1 & 7.1 & +2.4 & 5.6 & -0.7 & 23.1 & +6.8 & +1.5 \\
\hline Hungary $^{\mathrm{b}}$ & 10.4 & +6.7 & 5.5 & +1.0 & 4.5 & -0.7 & 20.4 & +7.0 & +2.7 \\
\hline Czech Rep. & 8.5 & +5.6 & 6.7 & +2.4 & 3.8 & -0.7 & 19.0 & +7.3 & +6.8 \\
\hline Ireland & 4.7 & +6.4 & 5.9 & +2.6 & 4.1 & -1.0 & 14.7 & +8.0 & +6.0 \\
\hline Spain & 8.6 & +7.1 & 6.6 & +2.4 & 3.7 & -0.6 & 18.9 & +8.9 & +2.9 \\
\hline Portugal $^{b}$ & 11.1 & +9.7 & 6.7 & +0.5 & -0.4 & -0.4 & 17.4 & +9.8 & +6.3 \\
\hline
\end{tabular}

a) Initial level: 2000.

b) Expenditure on long-term care not included in the projections.

c) Reduction in annual primary deficit ratios required to meet the government's intertemporal budget constraint in spite of the projected impact of ageing on age-related public expenditure ('T-3' variant of the ‘sustainability gap’ as defined in Economic Policy Committee, 2003)

Sources: for EU-25 countries: European Commission and Economic Policy Committee (2006) and European Commission (2006); for the US and Japan: OECD (2001, ch. 4) and Hauner et al. (2007).

Table 2 also shows that expected increases in expenditure on health and long-term care are now often larger than those projected for public pension schemes. Furthermore, these increases can even be bigger than is explained by purely demographic trends (cf. Table 1). The reason is that the projections related to actual policies also include an impact of technical progress on health costs that is independent of demographic change, 
but has consistently been observed in many countries in the past. ${ }^{5}$ It is impossible to predict whether these cost increases will continue if health systems and public finances are more and more under demographic pressure, or whether medical progress might change its direction in the future. There are thus substantial uncertainties concerning the future evolution of public health expenditure. It is worth noting, however, that longterm projections for health expenditure typically assume the cost-side effects of medical progress to become much weaker than they have been so far, so that they involve a substantial upward risk (see, e.g., Breyer and Ulrich 2000; Werding, 2007).

In any case, cost containment in the health-care sector is a major issue that remains to be addressed in many countries. The same applies to long-term care, where current levels of expenditure are smaller, while relative increases related to ageing are much more pronounced than in other areas. Thus far, no country has started to really deal with these problems. At least, certainly no country has found a key to avoiding continuous cost surprises without reducing the availability and/or the quality of services. Ideally, dealing with the prospects of increasing health costs could mean three things, alternatively or in combination. One could make attempts to reduce any inefficiencies involved in current systems of delivery and financing. One could try to push medical progress in a new, cost-saving direction. Or one must think about ways of paying for costly, high-quality medical services and of making them available for as many people as possible - in spite of the financial pressures through ageing. Partial pre-funding may thus also become an issue in health care and long-term care, as it already is in old-age provision. The distributive side of such reforms is probably even more delicate than it is with respect to pensions. Given this complication as well as the diversity of current national arrangements, there is apparently no one-size-fits-all solution which the countries affected most severely could simply borrow from each other.

\section{IV.3 Outlook: Re-organising the System of Intergenerational Transactions}

Basically, all the options for reform we have discussed here thus far are suitable, more or less, to mitigate the adverse consequences of ageing for the welfare state. In most countries, it is too late to avert ageing altogether as measures to increase mortality are ruled out as acceptable policy instruments. Higher immigration can slow down ageing processes, and it is most likely favourable for the welfare state in countries where age-

\footnotetext{
Otherwise, the projections are based on the assumption that age-specific morbidity decreases as life expectancy goes up (as in Table 1) and that there will be no special increase in costs near death through new forms of multi-morbidity, etc. (see Zweifel et al., 2004).
} 
ing is most severe (Werding and Munz, 2005). However, the numbers of immigrants to the developed world are immensely high that would be needed, with a very particular timing and geographical distribution, to keep current demographic dependency ratios constant over time. Increasing fertility rates, especially in countries where they have become extremely low, may also sound promising as a direct approach to slowing down ageing. But by the inertia of demographic processes, a higher number of children born today has an impact on the old-age dependency ratio only after 15 years, on the systems' dependency ratios of public pension schemes only after 20 years, and both types of effects become considerable only after 30 years or more. Still, fertility is particular in that it may be a determinant of demographic ageing which is affected by activities of the welfare state in a way that ought to be corrected, both for reasons of efficiency and for reasons of equity. We will therefore discuss this point and its potential policy implications as an outlook that concludes our previous considerations.

Public pay-as-you-go schemes covering expenditure with a strong age-related profile most notably pensions, but also health costs or education - are interventions in private systems of intergenerational transactions. They interfere with market-based arrangements based on savings, loans and insurance no less than with traditional arrangements mainly based on transactions within the family. In fact, public pay-as-you-go schemes providing for the old are mimicking the logic of these intra-family arrangements, allowing to insure against unfortunate outcomes of investment in education (see Meier and Wrede, 2010); yet, they do so in an imperfect way (Cigno, 1993). At the same time, they are actually funded, viz. by the human capital embodied in those who are expected to pay for future benefits. Therefore, the trouble with pay-as-you-go pension schemes as they are conventionally designed is that, for the individuals covered, they do not provide any incentives to invest in the human capital of the next generation of tax payers. Benefit entitlements are essentially assessed based on the amounts of financial contributions made, or the number of years for which this has been done. Raising children and investing in their education may therefore reduce one's own benefit entitlements, while it gives rise to a potentially huge fiscal externality in favour of other beneficiaries or tax payers of these systems.

It is true that this fiscal externality may become smaller through tax-financed public expenditure on education, child benefits, health care for children, etc. Some countries have even introduced child-related components of pension benefit entitlements - most notably, France (in 1974), Germany (in 1986), or Sweden (in 1998) - which are mainly meant to compensate for reductions in regular, earnings-related benefit entitlements associated with child-care activities (for descriptions and an in-depth analysis of the 
effects of these rules, see Cigno and Werding, 2007, ch. 4). However, in countries with generous, unfunded systems of old-age support and health insurance the total effect of all these measures still falls short by a substantial margin of the value of children as a funding source of public pensions, health care for the elderly, etc. (Werding, 2010).

Assuming that one of the reasons why people have children is an 'investment motive' related to old-age provision, economic theory clearly predicts a negative impact of this fiscal (net) externality on fertility (see, e.g., Cigno 1993). ${ }^{6}$ It appears that this effect of the introduction and expansion of unfunded public pensions is also empirically relevant (Cigno and Rosati, 1996; Ehrlich and Zhong, 1998; Ehrlich and Kim 2007), even though it certainly does not explain the entire decline in fertility rates observed in most developed countries. In any case, this line of reasoning leads to an efficiency case for reconsidering the way in which the welfare state currently intervenes in the field of intergenerational transactions. A parallel line of reasoning is about equity, both in an intergenerational and an intragenerational dimension. In conventional pay-as-you-go pension schemes, all contributors have to pay for members of the old generation who are currently drawing benefits. To make provisions for their own future benefit entitlements, they would also have to invest in children and in their future earnings capacity. However, this requirement is not reflected in the conventional design of pay-as-you-go pensions. Basically, generations with smaller average numbers of children have reduced this kind of investment. Scaling back their average benefit entitlements, e.g. by switching from DB to NDC schemes or by extending their active period of life, could therefore be considered appropriate (while applying equity norms to an intergenerational context is conceptually difficult). But as some people still have two or more children, while others have just one child or none, the former effectively providing for the pensions of the latter, equity considerations suggest to go even further in the revision of current systems.

A natural approach to reducing the fiscal externality of children together with the redistribution involved is to adapt the traditional design of unfunded pension schemes. In order to address the problem at its roots, this could be done by differentiating individual benefit entitlements by the number of children, respectively by the contributions of their children to the pension scheme (Sinn, 2004; Cigno and Werding, 2007, chs. 7 and 8; Meier and Wrede, 2010). When a (higher) fraction of unfunded pension entitlements

6 An alternative interpretation of the type of institutional failure that is relevant here is provided by Sinn (2004): taking unfunded public pensions to be an insurance against being childless, covering this risk through fully-fledged benefit entitlements in old age for all members creates unfavourable incentives for moral-hazard behaviour. 
becomes child-related, while average pension benefits have to be reduced for demographic reasons, this may have two types of behavioural consequences which are favourable with respect to the consequences of ageing for the welfare state. First, it may imply that higher complementary savings which are needed to deal with the ageing problem effectively concentrate among those with few or no children. On average, these people should have more resources available for doing so. Second, it may contribute to a recovery of current low fertility rates, rendering the welfare state more sustainable in the more remote future.

\section{REFERENCES}

Auerbach, A., Gokhale, J., and Kotlikoff, L. J. (1991), 'Generational Accounts: A Meaningful Alternative to Deficit Accounting', in: D. Bradford (ed.), Tax Policy and the Economy, vol. 5, Cambridge, MA, London, MIT-Press, pp. 55-110.

Blanchard, O. (1990), 'Suggestions for a New Set of Fiscal Indicators”, OECD Economics Department Working Paper, No. 79.

Börsch-Supan, A., Heiss, F., Ludwig, A., and Winter, J. (2003), 'Pension Reform, Capital Markets, and the Rate of Return'; German Economic Review 4(2): 151181.

Breyer, F. (1989), 'On the Intergenerational Pareto Efficiency of Pay-as-you-go Financed Pension Systems', Journal of Institutional and Theoretical Economics, 145(4): 643-658.

Breyer, F., and Ulrich, V. (2000), 'Gesundheitsausgaben, Alter und medizinischer Fortschritt: Eine Regressionsanalyse’, Jahrbücher für Nationalökonomie und Statistik 220(1): 1-17.

Brooks, R. (2000), 'What Will Happen to Financial Markets When the Baby Boomers Retire?', IMF Working Paper, No. WP/00/18.

Cigno, A. (1993), 'Intergenerational Transfers without Altruism: Family, Market and State', European Journal of Political Economy 9(4): 505-518.

Cigno, A., and Rosati, F. C. (1996), 'Jointly Determined Saving and Fertility Behaviour: Theory, and Estimates for Germany, Italy, UK and USA', European Economic Review 40(8): 1561-1589.

Cigno, A., and Werding, M. (2007), Children and Pensions, Cambridge, MA, London, MIT-Press.

Economic Policy Committee (2003), The Impact of Ageing Populations on Public Finances: Overview of Analysis Carried out at an EU Level and Proposals for a Future Work Programme, Doc. No. EPC/ECFIN/435/03. 
Ehrlich, I. B., and Kim, J. (2007), 'Has Social Security Influenced Family Formation and Fertility in OECD Countries? An Economic and Econometric Analysis', NBER Working Paper, No. W12869.

Ehrlich, I. B., Zhong, J.-G. (1998), 'Social security and the real economy: An inquiry into some neglected issues’, American Economic Review 88(2): 151-157.

European Commission (DG ECFIN, 2006), 'Public Finances in EMU 2006', European Economy, No. 3/2006.

European Commission and Economic Policy Committee (2006), 'The Impact of Ageing on Public Expenditure: Projections for the EU-25 Member States on Pensions, Health care, Long-term Care, Education and Unemployment Transfers', European Economy, No. 1/2006.

European Commission and Economic Policy Committee (2009), '2009 Ageing Report: Economic and Budgetary Projections for the EU-27 Member States', European Economy, No. 2/2009.

Fehr, H., Jokisch, S., and Kotlikoff, L. J. (2005), 'The Developed World's Demographic Transition: The Roles of Capital Flows, Immigration, and Policy', in: R. Brooks and A. Razin (eds.), Social security reform, Cambridge, Cambridge University Press, pp. 11-43.

Feldstein, M. S. (1995), 'Would Privatizing Social Security Raise Economic Welfare?’, NBER Working Paper, No. 5281.

Fenge, R. (1995), 'Pareto-efficiency of the Pay-as-you-go Pension System with Intragenerational Fairness', Finanzarchiv N.F., 52(3): 357-363.

Fenge, R., and Pestieau, P. (2005), Social Security and Early Retirement, Cambridge, MA, London, MIT-Press.

Fenge, R., and Werding, M. (2004), 'Ageing and the Tax Implied in Public Pension Schemes: Simulations for Selected OECD Countries', Fiscal Studies 25(2): 159200.

Hagemann, R., and Nicoletti, G. (1989), 'Population Ageing: Economic Effects and Some Policy Implications for Financing Public Pensions’, OECD Economic Studies, No. 12.

Hauner, D., Leigh, D., and Skaarup, M. (2007), 'Ensuring Fiscal Sustainability in G-7 Countries', IMF Working Papers, No. WP/07/187.

Haveman, R. H. (1994), 'Should Generational Accounts Replace Public Budgets and Deficits?’, Journal of Economic Perspectives 8(1): 95-111.

Meier, V., and Wrede, M. (2010), 'Pensions, Fertility, and Education', Journal of Pension Economics and Finance 9, forthcoming.

OECD (2001), Economic Outlook No. 69 (June 2001), Paris, Organisation for Economic Co-operation and Development. 
OECD (2006), Ageing and Employment Policies: Live Longer, Work Longer, Paris, Organisation for Economic Co-operation and Development.

OECD SOCX (2008), OECD Social Expenditure Database, 2008 Release, Paris, Organisation for Economic Co-operation and Development (download via http://www.oecd.org/els/social/expenditure).

OECD (2009), Pensions at a Glance 2009: Retirement-Income Systems in OECD Countries, Paris, Organisation for Economic Co-operation and Development.

Roseveare, D., Leibfritz, W., Fore, D., and Wurzel, E. (1996), 'Ageing Populations, Pension Systems and Government Budgets: Simulations for 20 OECD Countries', OECD Economics Department Working Paper No. 168.

Sinn, H.-W. (2000), 'Why a Funded Pension System is Needed and Why it is Not Needed', International Tax and Public Finance 7(4/5): 389-410.

Sinn, H.-W. (2004), 'The Pay-as-you-go Pension System as a Fertility Insurance and Enforcement Device', Journal of Public Economics 88(7/8): 1335-1357

UN Population Division (2009), World Population Prospects, 2008 Revision, New York, United Nations, Dept. of Economic and Social Affairs (download via http://www.un.org/esa/population/unpop.html).

Werding, M. (2007), 'Social Insurance: How to Pay for Pensions and Health Care?', in: I. Hamm, H. Seitz and M. Werding (eds.), Demographic Change in Germany: The Economic and Fiscal Consequences, Berlin, Heidelberg, New York, Springer, pp. 89-128.

Werding, M. (2010), 'The Economics of the Family and Its Policy Implications: Why Should We Care About Fertility Outcomes?', in: N. Takayama and M. Werding (eds.), Fertility and Public Policy: How to Reverse the Trend of Declining Birth Rates, Cambridge, MA, London, MIT-Press, forthcoming.

Werding, M., and Munz, S. (2005), 'Public Pensions and International Migration: Some Clarifications and Illustrative Results', Journal of Pension Economics and Finance 4(2): 181-207.

Whiteford, P. (2006), 'Increasing Employment Among Older Workers: Social Security Reform in OECD Countries - A Survey and Assessment', in: H. Emanuel (ed.), Ageing and the Labour market: Issues and Solutions, Or Are There?, Antwerpen, Oxford, intersentia, pp. 11-41.

Zweifel, P., Felder, S., and Werblow, A. (2004), 'Population Ageing and Health Care Expenditure: New Evidence on the «Red Herring’', Geneva Papers on Risk and Insurance, 29(4), 653-667. 


\section{CESifo Working Paper Series}

for full list see www.cesifo-group.org/wp

(address: Poschingerstr. 5, 81679 Munich, Germany, office@cesifo.de)

2853 Cletus C. Coughlin and Dennis Novy, Is the International Border Effect Larger than the Domestic Border Effect? Evidence from U.S. Trade, November 2009

2854 Johannes Becker and Clemens Fuest, Source versus Residence Based Taxation with International Mergers and Acquisitions, November 2009

2855 Andreas Hoffmann and Gunther Schnabl, A Vicious Cycle of Manias, Crashes and Asymmetric Policy Responses - An Overinvestment View, November 2009

2856 Xavier Vives, Strategic Supply Function Competition with Private Information, November 2009

2857 M. Hashem Pesaran and Paolo Zaffaroni, Optimality and Diversifiability of Mean Variance and Arbitrage Pricing Portfolios, November 2009

2858 Davide Sala, Philipp J.H. Schröder and Erdal Yalcin, Market Access through Bound Tariffs, November 2009

2859 Ben J. Heijdra and Pim Heijnen, Environmental Policy and the Macroeconomy under Shallow-Lake Dynamics, November 2009

2860 Enrico Spolaore, National Borders, Conflict and Peace, November 2009

2861 Nina Czernich, Oliver Falck, Tobias Kretschmer and Ludger Woessmann, Broadband Infrastructure and Economic Growth, December 2009

2862 Evžen Kočenda and Martin Vojtek, Default Predictors and Credit Scoring Models for Retail Banking, December 2009

2863 Christian Gollier and Martin L. Weitzman, How Should the Distant Future be Discounted when Discount Rates are Uncertain?, December 2009

2864 Tiberiu Dragu and Mattias Polborn, Terrorism Prevention and Electoral Accountability, December 2009

2865 Torfinn Harding and Beata Smarzynska Javorcik, A Touch of Sophistication: FDI and Unit Values of Exports, December 2009

2866 Matthias Dischinger and Nadine Riedel, There's no Place like Home: The Profitability Gap between Headquarters and their Foreign Subsidiaries, December 2009

2867 Andreas Haufler and Frank Stähler, Tax Competition in a Simple Model with Heterogeneous Firms: How Larger Markets Reduce Profit Taxes, December 2009 
2868 Steinar Holden, Do Choices Affect Preferences? Some Doubts and New Evidence, December 2009

2869 Alberto Asquer, On the many Ways Europeanization Matters: The Implementation of the Water Reform in Italy (1994-2006), December 2009

2870 Choudhry Tanveer Shehzad and Jakob De Haan, Financial Reform and Banking Crises, December 2009

2871 Annette Alstadsæter and Hans Henrik Sievertsen, The Consumption Value of Higher Education, December 2009

2872 Chris van Klaveren, Bernard van Praag and Henriette Maassen van den Brink, Collective Labor Supply of Native Dutch and Immigrant Households in the Netherlands, December 2009

2873 Burkhard Heer and Alfred Maußner, Computation of Business-Cycle Models with the Generalized Schur Method, December 2009

2874 Carlo Carraro, Enrica De Cian and Massimo Tavoni, Human Capital Formation and Global Warming Mitigation: Evidence from an Integrated Assessment Model, December 2009

2875 André Grimaud, Gilles Lafforgue and Bertrand Magné, Climate Change Mitigation Options and Directed Technical Change: A Decentralized Equilibrium Analysis, December 2009

2876 Angel de la Fuente, A Mixed Splicing Procedure for Economic Time Series, December 2009

2877 Martin Schlotter, Guido Schwerdt and Ludger Woessmann, Econometric Methods for Causal Evaluation of Education Policies and Practices: A Non-Technical Guide, December 2009

2878 Mathias Dolls, Clemens Fuest and Andreas Peichl, Automatic Stabilizers and Economic Crisis: US vs. Europe, December 2009

2879 Tom Karkinsky and Nadine Riedel, Corporate Taxation and the Choice of Patent Location within Multinational Firms, December 2009

2880 Kai A. Konrad, Florian Morath and Wieland Müller, Taxation and Market Power, December 2009

2881 Marko Koethenbuerger and Michael Stimmelmayr, Corporate Taxation and Corporate Governance, December 2009

2882 Gebhard Kirchgässner, The Lost Popularity Function: Are Unemployment and Inflation no longer Relevant for the Behaviour of Germany Voters?, December 2009

2883 Marianna Belloc and Ugo Pagano, Politics-Business Interaction Paths, December 2009 
2884 Wolfgang Buchholz, Richard Cornes and Dirk Rübbelke, Existence and Warr Neutrality for Matching Equilibria in a Public Good Economy: An Aggregative Game Approach, December 2009

2885 Charles A.E. Goodhart, Carolina Osorio and Dimitrios P. Tsomocos, Analysis of Monetary Policy and Financial Stability: A New Paradigm, December 2009

2886 Thomas Aronsson and Erkki Koskela, Outsourcing, Public Input Provision and Policy Cooperation, December 2009

2887 Andreas Ortmann, "The Way in which an Experiment is Conducted is Unbelievably Important": On the Experimentation Practices of Economists and Psychologists, December 2009

2888 Andreas Irmen, Population Aging and the Direction of Technical Change, December 2009

2889 Wolf-Heimo Grieben and Fuat Şener, Labor Unions, Globalization, and Mercantilism, December 2009

2890 Conny Wunsch, Optimal Use of Labor Market Policies: The Role of Job Search Assistance, December 2009

2891 Claudia Buch, Cathérine Tahmee Koch and Michael Kötter, Margins of International Banking: Is there a Productivity Pecking Order in Banking, too?, December 2009

2892 Shafik Hebous and Alfons J. Weichenrieder, Debt Financing and Sharp Currency Depreciations: Wholly vs. Partially Owned Multinational Affiliates, December 2009

2893 Johannes Binswanger and Daniel Schunk, What is an Adequate Standard of Living during Retirement?, December 2009

2894 Armin Falk and James J. Heckman, Lab Experiments are a Major Source of Knowledge in the Social Sciences, December 2009

2895 Hartmut Egger and Daniel Etzel, The Impact of Trade on Employment, Welfare, and Income Distribution in Unionized General Oligopolistic Equilibrium, December 2009

2896 Julian Rauchdobler, Rupert Sausgruber and Jean-Robert Tyran, Voting on Thresholds for Public Goods: Experimental Evidence, December 2009

2897 Michael McBride and Stergios Skaperdas, Conflict, Settlement, and the Shadow of the Future, December 2009

2898 Ben J. Heijdra and Laurie S. M. Reijnders, Economic Growth and Longevity Risk with Adverse Selection, December 2009

2899 Johannes Becker, Taxation of Foreign Profits with Heterogeneous Multinational Firms, December 2009 
2900 Douglas Gale and Piero Gottardi, Illiquidity and Under-Valuation of Firms, December 2009

2901 Donatella Gatti, Christophe Rault and Anne-Gaël Vaubourg, Unemployment and Finance: How do Financial and Labour Market Factors Interact?, December 2009

2902 Arno Riedl, Behavioral and Experimental Economics Can Inform Public Policy: Some Thoughts, December 2009

2903 Wilhelm K. Kohler and Marcel Smolka, Global Sourcing Decisions and Firm Productivity: Evidence from Spain, December 2009

2904 Marcel Gérard and Fernando M. M. Ruiz, Corporate Taxation and the Impact of Governance, Political and Economic Factors, December 2009

2905 Mikael Priks, The Effect of Surveillance Cameras on Crime: Evidence from the Stockholm Subway, December 2009

2906 Xavier Vives, Asset Auctions, Information, and Liquidity, January 2010

2907 Edwin van der Werf, Unilateral Climate Policy, Asymmetric Backstop Adoption, and Carbon Leakage in a Two-Region Hotelling Model, January 2010

2908 Margarita Katsimi and Vassilis Sarantides, Do Elections Affect the Composition of Fiscal Policy?, January 2010

2909 Rolf Golombek, Mads Greaker and Michael Hoel, Climate Policy without Commitment, January 2010

2910 Sascha O. Becker and Ludger Woessmann, The Effect of Protestantism on Education before the Industrialization: Evidence from 1816 Prussia, January 2010

2911 Michael Berlemann, Marco Oestmann and Marcel Thum, Demographic Change and Bank Profitability. Empirical Evidence from German Savings Banks, January 2010

2912 Øystein Foros, Hans Jarle Kind and Greg Shaffer, Mergers and Partial Ownership, January 2010

2913 Sean Holly, M. Hashem Pesaran and Takashi Yamagata, Spatial and Temporal Diffusion of House Prices in the UK, January 2010

2914 Christian Keuschnigg and Evelyn Ribi, Profit Taxation and Finance Constraints, January 2010

2915 Hendrik Vrijburg and Ruud A. de Mooij, Enhanced Cooperation in an Asymmetric Model of Tax Competition, January 2010

2916 Volker Meier and Martin Werding, Ageing and the Welfare State: Securing Sustainability, January 2010 